\title{
PENYULUHAN DAN PENGOLAHAN DATA SOSIAL EKONOMI PERIKANAN
}

\author{
Y Rahmat Akbar ${ }^{1)}$ \\ ${ }^{1)}$ Sekolah Tinggi Ilmu Ekonomi Persada Bunda \\ Email: yrahmat.akbar@stiepersadabunda.ac.id
}

\begin{abstract}
ABSTRAK
Kelemahan sistem data dan informasi perikanan merupakan tantangan dalam pengembangan usaha perikanan. Informasi data akan memberikan manfaat yang besar, terutama dalam pemanfaatan sumber daya perikanan yang berkelanjutan. Dengan optimalisasi penggunaan data statistik dan alat analisis khususnya kuantitatif akan memberikan keuntungan bagi peneliti dalam menghasilkan temuan maupun informasi yang detail mengenai perikanan. Kegiatan penyuluhan ini bertujuan untuk menambah pengetahuan dosen, mahasiswa maupun praktisi dari dinas yang terkait di bidang perikanan dalam penggunaan data dengan menggunakan alat statistik sehingga dapat memudahkan dalam proses pengolahan dan penelitian khususnya di bidang perikanan. Metode penyampaian materi dilakukan dengan presentasi, pelatihan dan simulasi, serta tanya-jawab dengan peserta yang bertujuan untuk mengetahui dan memberikan solusi atas kendala-kendala peserta dalam melakukan analisis data di bidang Sosial Ekonomi Perikanan. Dari hasil penyuluhan yang diberikan, ketercapaian tujuan kegiatan pengabdian dilihat dari pemahaman peserta dalam menyesuaikan penggunaan alat statistik sesuai dengan masalah penelitian, serta kemampuan peserta mengolah data.
\end{abstract}

Kata kunci: Pengolahan Data, Penyuluhan, Perikanan

\section{ABSTRACT}

Weaknesses in fisheries data and information systems are a challenge in developing a fisheries business. This data information will provide great benefits, especially in the sustainable use of fisheries resources. Optimizing the use of statistical data and analytical tools, especially quantitative, will benefit researchers in producing detailed findings and information about fisheries. This extension activity aims to increase the knowledge of lecturers, students and practitioners from related agencies in the field of fisheries in the use of data using statistical tools so that it can facilitate the processing and research, especially in the field of fisheries. The method of delivering the material is done with presentations, training and simulations, as well as questions and answers with participants who aim to find out and provide solutions to the constraints of the participants in conducting data analysis in the Social Economy of Fisheries. From the results of the counseling given, the achievement of the objectives of the service activities was seen from the participants' understanding of the suitability of the statistical tools with the research problem, and the ability of the participants to analyze the data.

Key words: Data Processing, Training, Fishery 


\section{PENDAHULUAN}

Indonesia merupakan negara maritim terbesar di dunia. Sesuai konvensi PBB mengenai Hukum Laut (UNCLOS) pada tahun 1982, wilayah nasional memiliki luas 5 juta $\mathrm{km} 2$. Luas ini terdiri dari 3,1 juta $\mathrm{km} 2$ perairan nasional, 1,9 juta $\mathrm{km} 2$ luas daratan serta Zona Ekonomi Ekslusif (ZEE) seluas 3,0 juta km2. Terdapat panjang garis pantai $81.000 \mathrm{~km}$ dengan pulau-pulau yang berjumlah kurang lebih 17.000 (Arsana, 2008). Perikanan merupakan kegiatan ekonomi dalam bidang penangkapan maupun budidaya hewan/tanaman air yang hidup bebas di laut dan perairan umum. Perikanan secara umum dibagi atas perikanan tangkap dan perikanan budidaya. Perikanan tangkap yaitu kegiatan ekonomi meliputi penangkapan, pengumpulan hewan atau tanaman air yang hidup di laut maupun perairan umum secara bebas. Sedangkan perikanan budidaya ialah kegiatan ekonomi meliputi pembudidayaan hewan atau tanaman air yang hidup di laut maupun perairan umum (Tangke, 2011).

Terbukanya peluang terhadap permintaan produksi perikanan Indonesia, maka semakin tinggi juga tuntutan untuk menaikkan produksi perikanan. Oleh karena itu, terdapat tantangan utama yang dihadapi dalam pembangunan perikanan untuk memenuhi permintaan tersebut yaitu peningkatan kualitas sumber daya manusia dalam penguasaan IPTEK dalam mendukung peningkatan produksi perikanan. Tantangan dalam pengembangan usaha perikanan di Indonesia yaitu masih lemahnya sistem informasi dan data perikanan yang akan mempengaruhi akurasi hasil penelitian. Hasil riset dan inovasi harus dapat dimanfaatkan, baik untuk stakeholder maupun masyarakat (Badan Riset dan SDM Kelautan dan Perikanan, 2019).

Pentingnya kemutakhiran data, akurasi dan kualitas data, berguna dalam mendukung program pemerintah. Untuk mempercepat berbagai proses pembangunan maka harus dimanfaatkan melalui kemajuan teknologi informasi. Beberapa kementerian selain Kementerian Kelautan dan Perikanan (KKP) juga sudah menuju platform teknologi informasi. Pemanfaatan data dapat mempercepat pelaksanaan program pembangunan Tanpa data yang akurat sebuah kebijakan atau program bisa salah sasaran dan akhirnya tidak memberikan manfaat (Kementerian Kelautan dan Perikanan, 2019).

Tantangan lain adalah kualitas sumber daya manusia. Untuk membangun suatu sistem informasi dibutuhkan sumber daya manusia yang mampu menguasai teknologi dalam pemanfaatan data statistik untuk mengoptimalkan potensi perikanan yang melimpah. Keterbatasan data dan informasi yang dapat dijadikan rujukan perencanaan dan pengelolaan sumber daya perikanan merupakan salah satu permasalahan pembangunan perikanan di Indonesia. Ketersediaan data dan informasi perikanan yang akurat sangat dibutuhkan dalam pembangunan perikanan nasional. Hal ini dikarenakan belum ada lembaga yang menangani penyediaan data dan informasi secara menyeluruh. Padahal ketersediaan informasi perikanan yang akurat merupakan faktor penting dalam menyusun perencanaan dan pengelolaan sumber daya perikanan, terutama untuk merencanakan pembangunan perikanan yang optimal serta berkelanjutan.

Dengan kegiatan penyuluhan ini diharapkan dapat menambah pengetahuan dosen, mahasiswa maupun praktisi dari dinas yang terkait di bidang perikanan dalam penggunaan data dengan menggunakan alat statistik sehingga dapat memudahkan dalam proses pengolahan dan penelitian. Optimalisasi penggunaan data statistik dan alat analisis 
khususnya kuantitatif akan memberikan keuntungan bagi peneliti dalam menghasilkan temuan maupun informasi yang detail mengenai perikanan.

\section{TINJAUAN PUSTAKA}

Statistik mulai digunakan awalnya pada bidang-bidang dalam matematika pada abad ke-19. Di abad ke 20, Ronald Fisher (peletak dasar statistika inferensi), Karl Pearson (metode regresi linear), dan William Sealey Gosset (peneliti problem sampel berukuran kecil) mulai mengembangkan cabang statistika untuk mendukung metode ilmiah dan statistika inferensi yang saat ini banyak digunakan. Saat ini, penggunaan statistik telah menyentuh di semua bidang ilmu pengetahuan. Bidang-bidang ilmu dan cabang-cabang terapannya, cukup banyak dipengaruhi oleh statistika dalam metodologinya. Oleh karena itu, lahirlah ilmu-ilmu gabungan seperti ekonometrika, biometrika (atau biostatistika), dan psikometrika (Wijaya, 2009).

Istilah statistika berasal dari bahasa Latin modern yaitu statisticum collegium yang artinya dewan negara dan bahasa Italia statista yang berarti negarawan atau politikus. Penerapan statistik ini dapat digunakan pada berbagai disiplin ilmu, baik ilmu-ilmu alam seperti astronomi dan biologi, ilmu-ilmu sosial seperti sosiologi dan psikologi, atau di bidang bisnis seperti ekonomi dan industri. Sedangkan penggunaan statistik pada pemerintahan digunakan untuk berbagai macam tujuan. Salah satunya seperti sensus penduduk, jajak pendapat atau polling misalnya dilakukan sebelum pemilihan umum, serta jajak cepat dalam perhitungan cepat hasil pemilu atau quick count. Di bidang komputasi, statistika dapat pula diterapkan dalam pengenalan pola maupun kecerdasan buatan.

Dalam metode penelitian penggunaan statistika merupakan bagian terpenting. Statistika dapat dipakai untuk alat bantu dalam pengambilan keputusan. Penelitian kuantitatif membutuhkan statistik sebagai alat bantu dalam penganalisaan data. Statistik memiliki fungsi untuk alat pembukti hipotesis, baik pada penelitian yang bersifat asosiasi (hubungan) maupun perbedaan. Fenomena statistik dalam penelitian sosial didominasi dengan sifat asosiasi (hubungan) dan diikuti dengan perbedaan (komparasi), namun tak jarang juga diawali dengan deskriptif (Black, 2013).

Dalam statistik, segala bentuk fenomena yang akan dianalisis diangkakan terlebih dahulu, baik angka yang bernilai mutlak atau tidak. Oleh sebab itu, skala pengukuran diperlukan pada penelitian yang menggunakan statistik.

Statistik diklasifikasikan menjadi dua yaitu (Hair, Black, Babin, \& Anderson, 2008):

1. Statistik Deskriptif

Merupakan menginterpretasikan transformasi data penelitian dalam bentuk tabulasi sehingga data tersebut mudah dipahami secara informatif. Deskriptif bersifat menggambarkan atau mendeskripsikan suatu kondisi dengan mempelajari tata cara pengumpulan, pencatatan, penyusunan, dan penyajian data penelitian dalam bentuk tabel frekuensi atau grafik, dan selanjutnya dilakukan pengukuran nilai-nilai statistik seperti dengan mean atau rerata.

2. Statistik Induktif atau Statistik Inferensial

Statistik yang bertugas memelajari tata cara penarikan kesimpulan mengenai keseluruhan populasi berdasarkan data hasil penelitian pada sampel (bagian dari populasi). 
Berdasarkan asumsi yang mendasarinya, statistik induktif juga dibedakan atas statistik parametrik dan non parametrik (Lind, Marchal, \& Wathen, 2008) yaitu:

1. Statistik Parametrik. Uji hipotesis atau pendugaan dari parameter populasi yang berdasar anggapan bahwa skor-skor analisis ditarik dari suatu populasi dengan distribusi tertentu. Sehingga menggunakan skala pengukuran interval atau ratio, serta data harus melalui uji normalitas (berdistribusi normal).

2. Statistik Nonparametrik. Uji hipotesis atau pendugaan dari parameter populasi yang berdasar anggapan bahwa skor-skor analisis ditarik tidak mengikuti distribusi tertentu pada suatu populasi (sebaran data bebas). Sehingga menggunakan skala pengukuran nominal atau ordinal, serta tidak mesti data berdistribusi normal.

Adapun jenis data terbagi atas sifatnya, cara memperoleh, sumber, dan cara penyusunan (Lind, Marchal, \& Wathen, 2007) yaitu:

1. Berdasarkan sifatnya, data terbagi atas data kualitatif dan data kuantitatif.

2. Berdasarkan cara memperolehnya, data terbagi atas data primer dan data sekunder.

3. Berdasarkan sumbernya, data terbagi atas data internal dan data eksternal.

4. Berdasarkan cara penyusunannya, data terbagi atas data nominal, data ordinal, data interval dan data ratio.

Beberapa sumber data perikanan yaitu https://siin.ristekdikti.go.id, sidatik.kkp.go.id, sirusa.bps.go.id, bappenas.go.id, bpsdmkp.kkp.go.id, kkp.go.id, bps.go.id, data.go.id, mangobay.co.id, katadata.co.id.

\section{METODE PELAKSANAAN}

Pengabdian ini berupa workshop pengolahan data dan penyuluhan perikanan yang dilaksanakan pada tanggal 27 September 2019 di Ruang Atlantik Fakultas Perikanan dan Kelautan Universitas Riau dengan peserta terdiri dari dosen, mahasiswa dan beberapa praktisi di bidang perikanan dengan jumlah lebih kurang sebanyak 82 orang.

Untuk melaksanakan kegiatan tersebut digunakan beberapa metode,yaitu:

a. Metode Ceramah

Metode ini digunakan untuk memberikan narasi dan pemaparan teori tentang statistik data untuk perikanan.

b. Metode Tanya Jawab

Metode ini penting untuk para peserta penyuluhan, baik saat menerima pemaparan maupun saat mempraktekkan alat analisis atau simulasi.

c. Metode Simulasi

Metode ini memberikan kesempatan kepada peserta penyuluhan untuk mempraktekan penggunaan alat analisis statistik.

\section{HASIL DAN PEMBAHASAN}

Dengan isi pemberian materi, praktek dan diskusi, peserta dibimbing dalam menerapkan hasil workshop dengan meningkatkan kemampuan peserta untuk melakukan pengolahan data kuantitatif. Berikut ini adalah tahapan yang dilakukan:

1. Tahap Persiapan

Adapun kegiatan dalam tahap persiapan meliputi : 
a. Survey

b. Penentuan lokasi dan sasaran

c. Penyusunan materi dan bahan penyuluhan

2. Tahap Pelaksanaan

Dalam pelaksanaan ini dilakukan pemaparan tentang teori statistik, sesi pertama menitikberatkan pada penjelasan statistik dan penggunaannya sesuai dengan permasalahan.

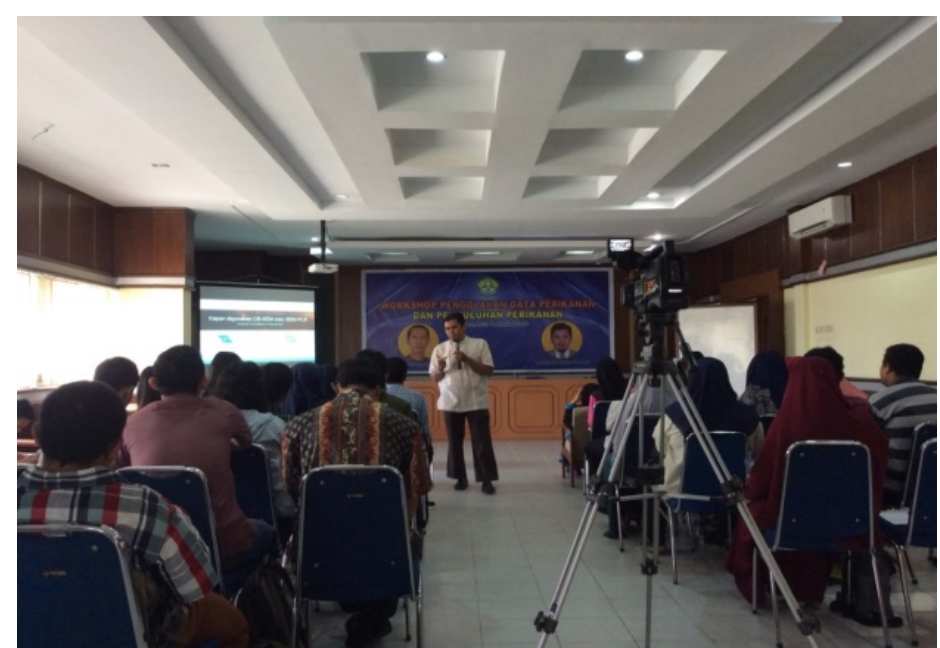

Gambar 1. Penyampaian Materi

kedua, sesi pelatihan menitikberatkan pada penggunaan aplikasi program statistik untuk lingkup perikanan.

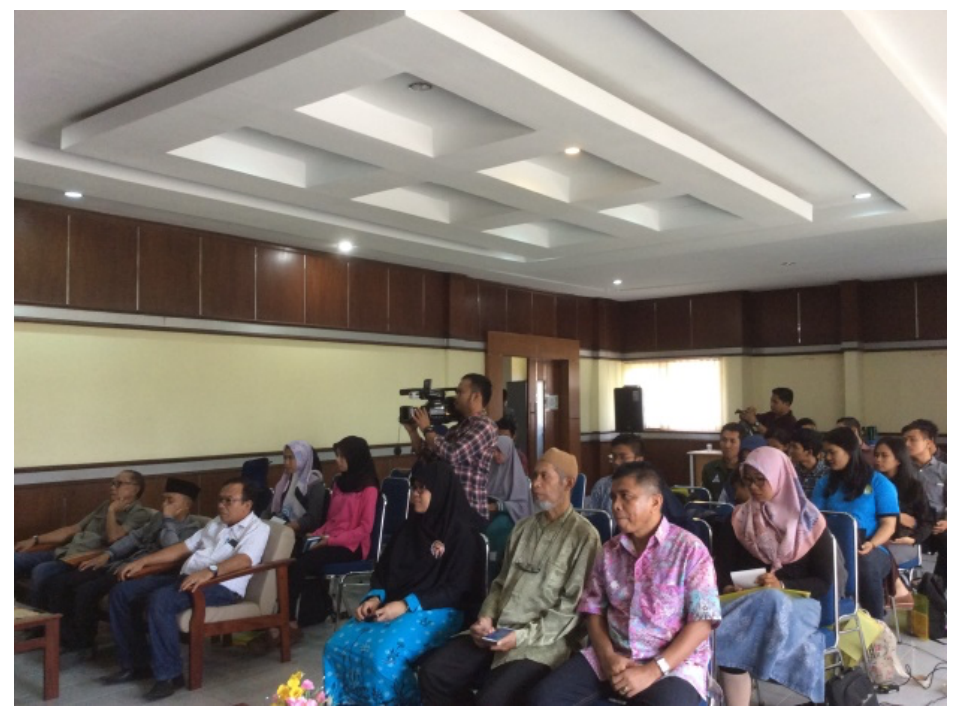

Gambar 2. Peserta sedang mendengarkan pemaparan materi

3. Rancangan Evaluasi

Evaluasi dilakukan selama proses penyuluhan, pada aspek pencapaian tujuan penyuluhan dan juga penyelenggaraan penyuluhan. Evaluasi proses dan hasil 
(pencapaian tujuan kegiatan pengabdian) menggunakan tanya jawab serta observasi. Adapun indikator keberhasilan dalam evaluasi dilakukan dengan 2 metode, yaitu:

a. Evaluasi selama proses kegiatan

Evaluasi saat pelaksanaan penyuluhan dilihat dari kemampuan dan keterlibatan peserta pada setiap tahap pelatihan. Pada tahap akhir, peserta diharapkan dapat melakukan kegiatan pengolahan data yaitu :

(1) memilih alat statistik dengan mengidentifikasi masalah penelitian, (2) membaca output statistik, (3) melakukan interpretasi dan mengambil kesimpulan awal dari hasil output statistik.

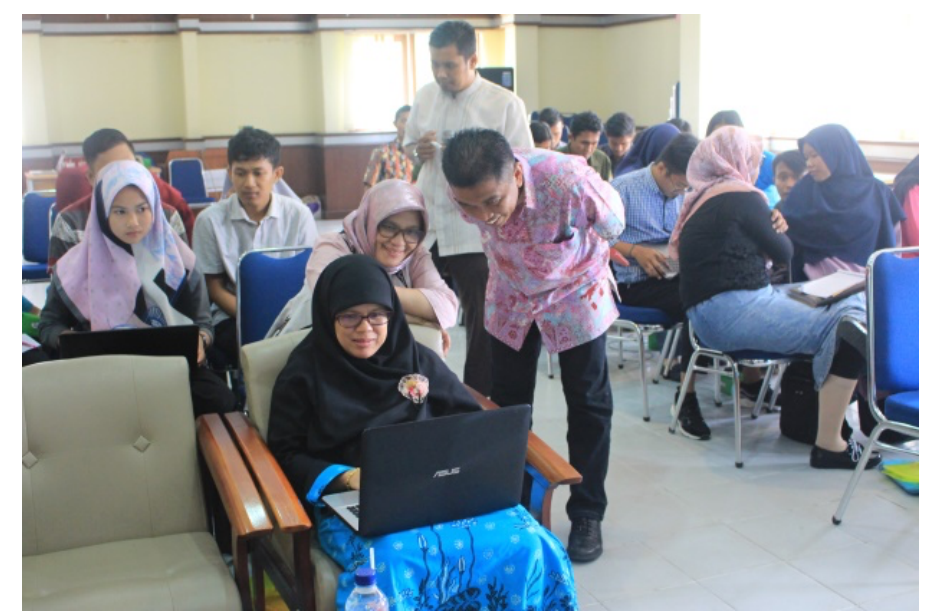

Gambar 3. Simulasi Pengolahan Data Perikanan

b. Evaluasi pasca kegiatan

Keberhasilan kegiatan pengabdian masyarakat ini dilihat berdasarkan taraf penyelesaian materi workshop dengan memeriksa hasil pengolahan data yang dibuat peserta pada saat pelatihan.

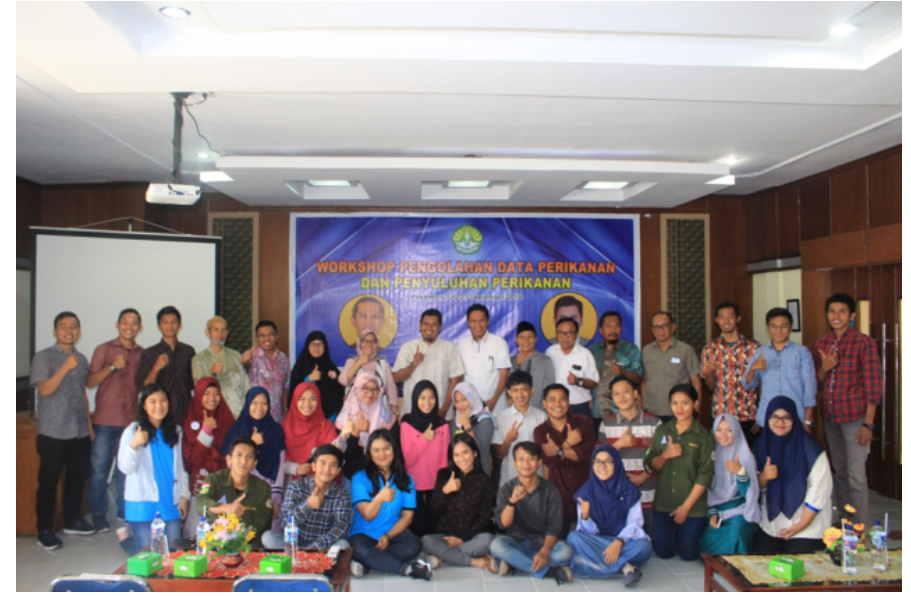

Gambar 4. Foto Bersama Peserta Penyuluhan dan Pengolahan Data Perikanan 


\section{KESIMPULAN}

Kegiatan workshop penyuluhan dan pengolahan data perikanan ini terlaksana dengan baik dengan hasil sebagian besar peserta dapat memahami materi dengan baik. Keaktifan peserta dalam proses kegiatan menunjukkan antusiasme peserta dalam kegiatan. Hal ini dapat dilihat dari pemahaman peserta dengan materi yang disampaikan dengan jenis data dan kasus yang berbeda menurut aplikasi praktek dan teori yang disampaikan. Ketercapaian tujuan kegiatan pengabdian dalam bentuk workshop dilihat dari kemampuan peserta dalam memahami penggunaan alat statistik sesuai dengan masalah penelitian, serta kemampuan peserta dalam mengolah data yang dilihat dari hasil latihan yang diberikan. Ketercapaian materi dilihat melalui hasil lembar evaluasi dengan hasil yang sebagian besar peserta dapat menguasai materi dengan baik.

Kemampuan peserta dalam memahami materi ditunjukkan dari kemampuan peserta dalam menyelesaikan tugas yang diberikan serta kemampuan dalam menjawab setiap pertanyaan-pertanyaan yang diberikan oleh pelaksana kegiatan. Peserta merasa terbantu dengan adanya kegiatan ini karena bagian kompetensi dalam melakukan penelitian. Berdasarkan evaluasi dari kegiatan pengabdian yang telah dilakukan, dapat diusulkan saran untuk kegiatan analisis statistik lanjutan dengan konsekuensi tambahan waktu dan biaya serta perlunya kegiatan lanjutan yang tidak terbatas hanya pada pengolahan data namun pendampingan penyuluhan dan publikasi.

Dalam pelaksanaan kegiatan pengabdian ini tidak lupa kami ucapkan terima kasih yang sebesar-besarnya kepada Dekan Fakultas Perikanan dan Ilmu Kelautan terkhusus Ketua Jurusan Sosial Ekonomi Perikanan beserta jajarannya atas kerjasamanya, Lembaga Penelitian Pengabdian Masyarakat Yayasan Pendidikan Persada Bunda serta seluruh peserta penyuluhan yang antusias mengikuti kegiatan dimaksud.

\section{DAFTAR PUSTAKA}

[1]. Arsana, I. (2008). The Delineation of Indonesia's Outer Limits of Its Extended Contitental Shelf and Preparation for Its Submission: Status and Problems. New York: Division for Ocean Affairs and The Law of The Sea Office of Legal Affairs, The United Nations.

[2]. Badan Riset dan SDM Kelautan dan Perikanan. (2019). BRSDM Ajak Stakeholders Manfaatkan Data Riset. Retrieved 2019, from Badan Riset dan Sumber Daya Manusia Kelautan dan Perikanan: https://kkp.go.id/brsdm/artikel/12858-brsdm-ajakstakeholders-manfaatkan-data-riset

[3]. Black, K. (2013). Applied Business Statistics: Making Better Business Decisions (7th Edition). International Student Version.

[4]. Hair, J., Black, W., Babin, B., \& Anderson. (2008). Multivariate Data Analysis 5th Edition. New Jersey: Prentice Hall International Inc.

[5]. Kementerian Kelautan dan Perikanan. (2019). Keterbukaan Informasi dan Program Satu Data KKP. Retrieved 2019, from Satu Data: https://kk.go.id/setjen/satudata/artikel/5377-keterbukaan-informasi-dan-programsatu-data-kkp 
[6]. Lind, D. A., Marchal, W. G., \& Wathen, S. A. (2007). Teknik-Teknik Statistika dalam Bisnis dan Ekonomi Menggunakan Kelompok Data Global, Buku 1. Jakarta: Salemba Empat.

[7]. Lind, D. A., Marchal, W. G., \& Wathen, S. A. (2008). Statistical Techniques in Business and Economics with Global Data Sets, 13th ed. New York: McGraw-Hill Companies, Inc.

[8]. Tangke, U. (2011). Pemanfaatan Sistem Informasi Perikanan Dalam Pengelolaan Sumberdaya. Jurnal Ilmiah agribisnis dan Perikanan Volume 4 Edisi 2, 52-56.

[9]. Wijaya, T. (2009). Analisis Structural Equotion Modeling Menggunakan AMOS. Yogyakarta: Universitas Atmajaya. 